\title{
Program Belajar Siswa \\ Berbasis Prinsip Progressive Differentiation dan Intergrative Reconciliation
}

\author{
Nathasa Pramudita Irianti ${ }^{1}$ *, Elita Mega Selvia Wijaya ${ }^{1}$ \\ ${ }^{1}$ Program Studi Pendidikan Matematika, Universitas Tribhuwana Tunggadewi. Jalan Telaga Warna, \\ Tlogomas, Malang 65144, Indonesia. \\ * Korespondensi Penulis. E-mail: nathasa1990@gmail.com, Telp: +628563443483
}

Article received: 06-10-2018, article revised : 28-02-2019, article published: 31-03-2019

DOI : 10.25273/jipm.v7i2.3280

\begin{abstract}
Abstrak
Penelitian ini bertujuan untuk menghasilkan program belajar siswa berupa lembar kerja siswa dan rencana pelaksanaan pembelajarannya berbasis prinsip Progressive Differentiation dan Integrative Reconciliation pada materi pernyataan majemuk dan berkuantor yang valid, praktis, dan efektif. Jenis penelitian ini adalah penelitian pengembangan. Pengembangan program belajar ini berdasar pada Four-D Model (Model 4D) yang telah dimodifikasi, yaitu Define (Pendefinisian), Design (Perancangan), dan Develop (Pengembangan). Tahap Disseminate (Penyebarluasan) tidak dilakukan karena keterbatasan waktu. Untuk mengetahui keterlaksanaan kriteria yang ditetapkan, maka dilakukan uji ahli dan uji coba lapangan. Subjek uji coba pengembangan desain pembelajaran ini adalah 25 siswa di SMA Panjura Malang. Berdasarkan hasil analisis data, program belajar dapat diterapkan dan terlaksana dengan baik. Hal ini ditunjukkan dari hasil uji ahli kepada tiga ahli yang memberikan hasil valid dengan persentase penilaian $73 \%$ untuk RPP dan $83 \%$ untuk LKS. Isi dan kalimat mudah dimengerti serta gambar yang disajikan jelas dengan hasil $85 \%$ massuk dalam kategori praktis. Waktu yang disediakan untuk menyelesaikan kegiatan pada LKS mencukupi dan masuk dalam kategori praktis dengan nilai $81,5 \%$. Selanjutnya uji coba lapangan program belajar dilakukan kepada 25 siswa SMA Panjura dengan nilai rata-rata skor 85,28 yang masuk dalam kategori sangat baik. Data keefektifan LKS diperoleh dari hasil belajar siswa dan respon siswa. Hasil tes belajar siswa uji coba latihan I dan II yang masing-masing mendapatkan skor rata-rata 82,08 dan 80,96 yang juga masuk dalam kategori sangat baik. Dari sini diketahui bahwa program belajar siswa praktis dan efektif untuk diterapkan dalam pembelajaran.
\end{abstract}

Kata Kunci: Program Belajar; Prinsip Progressive Differentiation; Pronsip Integrative Reconciliation

\begin{abstract}
The research aims to create student learning programs in the form of student worksheets and it's lesson plan based on the principles of Progressive Differentiation and Integrative Reconciliation that valid, practical, and effective. This type of research is development research. The development of this learning program is based on the Four-D Model that consist of Define, Design, and Develop. To find out the implementation of this program, validation and field trials are carried out. The subject of this learning design development trial were 25 students at Panjura High School Malang. Based on the results of data analysis, mathematics learning programs based on the Principles of Progressive Differentiation and Integrative Reconciliation can be implemented. It showed by examinations of three experts who gave valid results with a percentage of $73 \%$ for the lesson plans and $83 \%$ for student woorksheets. The contain on students worksheets are easy to understand and clear with $85 \%$ result in the practical category. The time that given for student to finish the worksheet is sufficient and can be categorized as practical with percentage $81,5 \%$. Furthermore, the learning program trial was conducted on 25 Panjura High School students with an average score of 85.28 which was included in the excellent category. Data on worksheet effectiveness is obtained form student learning outcomes and student responses. The learning test results of the test students in exercises I and II, each of which
\end{abstract}


JIPM (Jurnal Ilmiah Pendidikan Matematika), 7(2), Maret 2019- 75

Nathasa Pramudita Irianti, Elita Mega Selvia Wijaya

got an average score of 82.08 and 80.96 which also included in the excellent category. From here it is known that the student learning program is practical and effective to be applied in learning.

Keywords: Learning program; Progressive Differentiation Principle; Integrative Reconciliation Principle

\section{PENDAHULUAN}

Menurut National Council of Teachers of Mathematics (NCTM) (2000), pemahaman matematis merupakan hal yang sangat penting dalam pembelajaran matematika. Hal ini sejalan dengan Mathematics Learning Study Committee, National Research Council (NRC), Amerika Serikat yang dikutip oleh Kilpatrick, Swafford, dan Findell (2002) yang menjelaskan bahwa pemahaman konsep merupakan salah satu dari lima kecakapan matematis yang harus dikuasai siswa dalam pembelajarannya. Bani (2011) menambahkan bahwa kemampuan pemahaman matematis adalah salah satu tujuan penting dalam pembelajaran matematika yang bukan hanya sebagai hafalan.

Namun pada kenyataannya, pemahaman konsep matematis siswa dirasa belum optimal (Afrilianto, 2012). Masih banyak ditemui kesulitan-kesulitan peserta didik dalam memahami konsep matematika. Fakta tentang rendahnya pemahaman konsep matematis siswa dapat dilihat dari penelitian-penelitian terdahulu seperti yang dilakukan oleh Huda \& Kencana, (2013), Sukmara (2011), Ningsih (2013), Febriyanto, Haryanti, \& Komalasari (2018), Murizal, Yarman, \& Yerizon (2012) yang menunjukkan kemampuan pemahaman konsep matematis siswa masih sangat rendah.

Berdasarkan hasil wawancara dengan guru matematika di SMA Panjura, diketahui bahwa untuk materi pernyataan majemuk dan berkuantor, lebih dari $50 \%$ siswa belum memenuhi kriteria kelulusan minimum (KKM) sekolah. Menurutnya, siswa hanya menghafal materi tanpa memahami konsepnya. Materi pernyataan majemuk dan berkuantor merupakan bagian ilmu matematika yang digunakan untuk menentukan suatu keputusan. Karakteristik materi ini dalam cakupan luas merupakan suatu dasar pola pikir yang sistematis. Ketika siswa mampu menyelaraskan logika dalam struktur kognitifnya, maka siswa mampu melihat berbagai hubungan yang ada pada materi ini. Sayangnya, masih banyak siswa yang belum dapat memahaminya dan masih sekedar menghafal. Penelitian-penelitian mengenai pembelajaran matematika materi pernyataan majemuk dan berkuantor sudah banyak dilakukan, diantaranya Alawiah, Rahmatina, \& Febrian (2018), Musrikah (2016), Harini \& Oka, (2016), Pramuditya, Noto, \& Purwono (2018), Yulianti, Zulkardi, \& Siroj (2010). Dari penelitian ini, terlihat bahwa terdapat modifikasi dalam proses pembelajaran materi pernyataan majemuk dan berkuantor.

Menurut beberapa penelitian, rendahnya pemahaman konsep matematis siswa ini disebabkan oleh beberapa hal, diantaranya adalah ketakutan terhadap matematika (Irianti, Subanji, \& Chandra, 2016), pembelajaran yang masih terpusat pada guru (Maisari Dwi, Suyadi Gimin, 2013), hafalan (Wijaya \& Irianti, 2017). Pemahaman konsep yang masih rendah ini dapat diatasi jika tujuan utama dalam pembelajaran ditekankan untuk membangun pemahaman yang mendalam (Crawford, 2001). Hal ini didukung oleh pernyataan Johnson (2002) bahwa menemukan makna dapat memberi alasan untuk belajar. Robert E. Slavin dalam bukunya Educational Psychology (Slavin, 1997) menyatakan bahwa pembelajaran bermakna adalah pemrosesan mental dari informasi baru yang terhubung dengan ilmu pengetahuan yang dimiliki. Guru dapat membantu siswa mempelajari informasi dalam suatu cara yang akan membuat informasi dapat digunakan seperti layaknya menjadi bermakna bagi mereka. Mayer (Anderson et al., 2001) mengemukakan bahwa ciri dari pembelajaran yang bermakna adalah jika siswa dapat menggunakan pengetahuan yang dipelajari untuk memecahkan masalah dan memahami konsep-konsep baru dengan cara mentransfer pengetahuannya untuk situasi dan masalah yang baru. Agar terjadi pembelajaran bermakna, konsep atau informasi yang baru harus dikaitkan dengan konsep-konsep yang sudah ada di dalam struktur kognitif siswa.

Seorang ahli Psikologi Ausubel (1963) mengemukakan bahwa faktor utama yang mempengaruhi tercapainya pembelajaran bermakna adalah struktur kognitif seseorang atau dalam hal ini adalah siswa. Ausubel memaparkan prinsip Progressive Differentiation dan Integrative Reconciliation untuk 
merencanakan isi sajian materi agar materi itu selaras dengan struktur kognitif siswa. Prinsip

Progressive Differentiation adalah prinsip dalam perencanaan sajian materi pelajaran dalam pembelajaran bermakna. Pada prinsip ini ide pokok materi itu ditampilkan terlebih dahulu kemudian secara bertahap ide pokok dibedakan menjadi submateri menurut suatu kriteria pembeda. Sedangkan pada prinsip Integrative Reconciliation, submateri submateri itu digabungkan secara menyeluruh melalui hubungannya dalam kesatuan materi. Dengan demikian, prinsip Integrative Reconciliation dilakukan dengan mencari hubungan antar ide, menunjukkan persamaan dan perbedaan yang penting, dan menggabungkan hal yang tampak belum jelas. Ahli psikologi Travers, Elliott, \& Kratochwill (1993) dan Slavin (1997) memperkuat teori pembelajaran bermakna Ausubel ini.

Pembelajaran matematika yang bermakna juga tidak lepas dari bahan ajar dan rencana pelaksanaan pembelajaran yang terintegrasi dalam suatu program belajar yang dapat menuntun siswa ke dalam pembelajaran yang bermakna. Salah satu bentuk alternatif bahan ajar yang dapat digunakan dalam proses pembelajaran, khususnya pembelajaran matematika adalah penggunaan bahan ajar cetak seperti Lembar Kerja Siswa (LKS). LKS merupakan lembaran-lembaran yang berisi tugas, petunjuk, serta langkah-langkah yang harus dikerjakan oleh siswa (Pendidikan, 2007). Menurut Prastowo (2015), dengan LKS siswa dapat menemukan arahan yang terstruktur untuk memahami materi yang diberikan. Namun pada kenyataannya, ketersediaan LKS yang memuat proses pembelajaran yang bermakna serta mendukung tercapainya tujuan pembelajaran matematika masih dirasa kurang (Gazali, 2016). Oleh karena itu perlu adanya suatu program belajar berupa Lembar Kerja Siswa (LKS) yang dilengkapi dengan rencana pembelajarannya yang dapat menuntun siswa dalam pembelajaran yang bermakna.

Penggunaan bahan ajar berbentuk Lembar Kerja Siswa (LKS) dan perangkat pembelajaran yang menggunakan prinsip Progressive Differentiation dan Integrative Reconciliation diharapkan dapat menjadikan proses pembelajaran lebih bermakna (meaningful). Oleh karena itu, peneliti melakukan penelitian mengenai pengembangan program belajar berupa LKS dengan prinsip
Progressive Differentiation dan Integrative Reconciliation pada pembelajaran matematika.

\section{METODE}

Pengembangan program belajar siswa berbasis Prinsip Progressive Differentiation dan Integrative Reconciliation ini termasuk dalam jenis penelitian pengembangan. Program belajar yang akan dikembangkan berbentuk Lembar Kerja Siswa (LKS) dilengkapi dengan Rencana Pelaksanaan Pembelajarannya (RPP) dan soal tes hasil belajar (Bermain dengan Logika I dan II). Model pengembangan yang digunakan adalah Four-D Model (Model Empat-D) yang diadopsi dari Thiagarajan \& Sivasailam (1920). Four-D terdiri dari empat tahapan, yaitu Define (Pendefinisian), Design (Perancangan), Develop (Pengembangan) dan Disseminate (Penyebarluasan). Tahap disseminate (Penyebarluasan) tidak dilakukan karena keterbatasan waktu penelitian. Penelitian ini dilaksanakan di SMA Panjura Malang. Subjek Uji Coba adalah 25 siswa XI IPA 3 SMA Panjura Malang.

Pada tahap Define terdiri dari empat langkah yaitu (a) tahap Front-end analysis (Analisis Awal-Akhir) yaitu mengumpulkan informasi tentang perangkat pembelajaran yang sudah digunakan untuk mengetahui apa yang perlu dikembangkan. Pengumpulan informasi ini dilakukan wawancara tehadap guru matematika di SMA Panjura Malang (b) Pada tahap Learner Analysis (Analisis Pebelajar), yang dilakukan adalah wawancara dengan guru matematika di Panjura untuk mengetahui kurikulum yang digunakan di SMA Panjura dan bahan ajar yang digunakan untuk kebutuhan pengembangan program belajar yang akan dikembangkan. (c) tahap Task Analysis (analisis tugas), yang dilakukan adalah wawancara dengan guru untuk memperoleh gambaran mengenai tugas dan latihan yang biasa diberikan dalam pembelajaran matematika. (d) tahap Concept Analysis (Analisis Konsep) yang dilakukan adalah identifikasi materi yang akan dipelajari, yaitu pernyataan majemuk dan berkuantor serta analisis karakteristik siswa untuk mengetahui karakteristik siswa SMA Panjura secara umum mengenai cara berpikir siswa dengan cara wawancara dan observasi.

Pada tahap Design (Perancangan) terdiri dari (a) Conctructing Criterion-Referenced Test (Menyusun Tes Berbasis Kriteria), dilakukan 
penyusunan kisi-kisi latihan pada Lembar Kerja Siswa dilengkapi dengan kunci jawaban dan pedoman penskoran serta penyusunan desain instrumen, bertujuan agar alat untuk menilai LKS yang dikembangkan bisa benar-benar valid (b) media selection (pemilihan media). Bahan ajar yang dipilih dalam pengembangan program belajar ini adalah Lembar Kerja Siswa (LKS) dikarenakan sekolah SMA Panjura sudah terbiasa menggunakan LKS dalam pembelajarannya, akan tetapi LKS yang biasa digunakan belum menuntun pada pemahaman matematis siswa. Oleh karena itu, LKS yang disusun dilengkapi dengan Rencana Pelaksanaan Pembelajaran (RPP), hal ini bertujuan untuk mempermudah LKS dalam pembelajaran. RPP yang disusun berisi petunjuk-petunjuk penggunaan LKS dan jumlah pertemuan (c) format selection (pemilihan format), dipilihlah Prinsip Progressive Differentiation dan Integrative Reconciliation yang digunakan dalam pembelajaran. Dan langkah terakhir (d) Initial Design (Rancangan Awal) yaitu Program Belajar siswa berupa Lembar Kerja Siswa (LKS) dilengkapi dengan Rencana Pelaksanaan Pembelajaran (RPP) menggunakan Prinsip Progressive Differentiation dan Integrative Reconciliation pada materi Pernyataan Majemuk dan Berkuantor.

Pada tahap Develop (Pengembangan), dilakukan Expert Appraisal (Penilaian Ahli) dan Developmental Testing (Uji Pengembangan). Expert Appraisal (Penilaian Ahli) merupakan cara untuk memperoleh saran demi perbaikan dari rancangan Lembar Kerja Siswa (LKS) dan RPP. Para ahli yang terdiri dari tiga Dosen Pendidikan Matematika yang merupakan ahli materi sekaligus ahli pendidikan menilai dan memberikan tanggapan terhadap rancangan LKS yang telah dibuat. Dari sini dapat diketahui apakah LKS dan RPP yang telah disusun tersebut layak untuk dilanjutkan pada tahap selanjutnya yaitu Developmental Testing, apakah masih perlu dilakukan revisi perbaikan. Pengumpulan data dilakukan menggunakan instrumen pengumpulan data dengan skala penilaian 1 sampai 5 dan lembar saran. Data yang telah diperoleh selanjutnya diolah menggunakan rumus sebagai berikut:

$$
P=\frac{\sum_{1}^{3} x_{i}}{\sum_{1}^{3} x_{j}} \times 100 \%
$$

Keterangan:

$P \quad$ : presentase pilihan $\sum_{1}^{3} x_{i} \quad$ : total skor penilaian oleh subjek uji ahli $\sum_{1}^{3} x_{j} \quad$ : total skor maksimum

Untuk mengetahui apakah LKS, RPP, dan soal tes hasil belajar yang telah disusun sudah valid atau tidak, perlu dilakukan revisi atau tidak, maka digunakan pedoman penilaian kevaliditasan rancangan program belajar seperti tabel 1 berikut.

Tabel 1. Pedoman Penilaian Kevaliditasan Rancangan Program Belajar Siswa (Sumber: Arikunto, 2010))

\begin{tabular}{ccc}
\hline Presentase (\%) & $\begin{array}{c}\text { Kriteria } \\
\text { Kevaliditasan }\end{array}$ & Keterangan \\
\hline $80-100$ & Sangat Valid & Tidak Revisi \\
\hline $66-79$ & Valid & Tidak Revisi \\
\hline $55-65$ & Cukup Valid & Tidak Revisi \\
\hline $40-55$ & Kurang Valid & Revisi \\
\hline $30-39$ & Tidak Valid & Revisi \\
\hline
\end{tabular}

Jika hasil uji ahli minimal memenuhi kriteria cukup valid, maka rancangan LKS, RPP dan soal tes hasil belajar yang telah dibuat sudah dapat diujicobakan kepada siswa. Selanjutnya pada tahap Developmental Testing (Uji Pengembangan), rancangan LKS, RPP dan soal tes hasil belajar yang telah memenuhi kriteria minimal validitas dan telah diperbaiki sesuai saran dan komentar dari para ahli, diujicobakan kepada siswa SMA Panjura Malang. Instrumen uji coba program belajar berupa Lembar Kerja Siswa (LKS) yang bertujuan untuk mengetahui tingkat pemahaman siswa terhadap sajian materi yang ada di dalamnnya. Subjek uji coba LKS ini terdiri dari 25 siswa XI IPA 3. Data yang diperoleh selanjutnya diolah menggunakan pedoman penilaian kepraktisan dan keefektifan. Pedoman penilaian keefektifan rancangan program belajar siswa pada Tabel 2 berikut.

Tabel 2. Pedoman Penilaian Keefektifan

Rancangan Program Belajar Siswa (Sumber: Arikunto, 2010))

\begin{tabular}{cc}
\hline Skor Siswa & Keterangan \\
\hline $80-100$ & Baik Sekali \\
\hline $66-79$ & Baik \\
\hline $55-65$ & Cukup \\
\hline $40-55$ & Kurang \\
\hline $30-39$ & Gagal \\
\hline
\end{tabular}

Sedangkan instrumen pengumpulan data untuk melihat kepraktisan program belajar menggunakan angket kepraktisan LKS yang 
ditujukan kepada siswa, lembar obsevsi keterlaksanaan LKS, dan wawancara terhadap guru. Praktikalitas LKS dilihat dari segi kemudahan penggunaan, keterbacaan, isi, dan waktu. Data yang diperoleh dari angket kepraktisan LKS dideskripsikan dengan teknik analisis frekuensi data dengan rumus, yaitu:

Tingkat praktikalitas $=\frac{\text { skor } \text { rata-rata }}{\text { skor maksimum }} \times 100 \%$

Kemudian nilai yang diperoleh diklasifiksikan berdasarkan kriteria yang dikemukakan oleh Riduwan(Riduwan, 2006) dengan kriteria pada tabel 3. Nilai praktikalitas LKS yang dianggap cukup untuk dilanjutkan pada tahap berikutnya apabila mencapai nilai $\geq 65$.

Tabel 3. Pedoman Penilaian Kepraktisan Program Belajar Siswa

\begin{tabular}{cc}
\hline Nilai & Keterangan \\
\hline $90 \leq \mathrm{x} \leq 100$ & Sangat Praktis \\
\hline $80 \leq \mathrm{x}<90$ & Praktis \\
\hline $65 \leq \mathrm{x}<80$ & Cukup Praktis \\
\hline $55 \leq \mathrm{x}<65$ & Kurang Praktis \\
\hline $0 \leq \mathrm{x}<55$ & Tidak Praktis \\
\hline
\end{tabular}

\section{HASIL DAN PEMBAHASAN}

\section{Define (Pendefinisian)}

Tahap define terdiri dari empat langkah, yaitu Front-end analysis (Analisis Awal-Akhir), Learner Analysis (Analisis Pebelajar), Task Analysis (Analisis Tugas) dan Concept Analysis (Analisis Konsep).

Tahap Front-end analysis (Analisis AwalAkhir) dilakukan dengan wawancara kepada guru matematika SMA Panjura. Hasilnya menunjukkan bahwa siswa sudah menggunakan Lembar Kerja Siswa (LKS) dalam pembelajaran matematikanya, namun isi LKS yang digunakan hanya berisi contoh soal dan pembahasan, serta latihan soal. Siswa sekedar meniru dan menghafal. Proses pembelajaran yang bermakna belum dapat dimunculkan dari penggunaan LKS ini. Kutipan wawancara peneliti dengan guru matematika di SMA Panjura dapat dilihat pada gambar 1.

$\begin{array}{ll}\text { PENELITI : } & \text { Apakah dalam pembelajaran materi } \\ & \text { pernyataan majemuk dan } \\ & \text { berkuantor menggunakan Lembar } \\ & \text { Kerja Siswa (LKS)? } \\ \text { GURU : } & \text { Iya } \\ \text { PENELITI : } & \text { Apa isi di dalam Lembar Kerja } \\ & \text { Siswa (LKS) tersebut? } \\ \text { GURU } & \text { Materi, contoh soal dan } \\ & \text { pembahasannya, dan latihan soal } \\ & \text { saja. } \\ \text { PENELITI : } & \text { Apakah siswa merasa lebih mudah } \\ & \text { dalam menggunakan LKS? } \\ \text { GURU } & \text { Siswa kurang memahami materi } \\ & \text { karena isi LKS hanya contoh soal } \\ & \text { dan pembahasannya sehingga } \\ & \text { Siswa cenderung meniru dan } \\ & \text { menghafal dalam menyelesaikan } \\ & \text { soal dan jika soal yang diberikan } \\ & \text { berbeda siswa tidak dapat } \\ & \text { mengerjakan soal tersebut. }\end{array}$

Gambar 1. Kutipan Wawancara

Pada tahap Learner Analysis (Analisis Pebelajar), didapatkan bahwa siswa juga tidak memiliki bahan ajar lain selain yang diberikan oleh guru. Di tahap Task Analysis (analisis tugas), diperoleh gambaran mengenai tugas dan latihan yang biasa diberikan dalam pembelajaran matematika. Di tahap Concept Analysis (Analisis Konsep) yang merupakan bagian terakhir dari tahap Define, dilakukan identifikasi materi yang akan dipelajari, yaitu pernyataan majemuk dan berkuantor.

\section{Design (Penyusunan)}

Tahap design terdiri dari Conctructing Criterion-Referenced Test (Menyusun Tes Berbasis Kriteria), Media Selection (Pemilihan Media), Format Selection (Pemilihan Format) dan Initial Design (Rancangan Awal).

Pada Conctructing Criterion-Referenced

Test (Menyusun Tes Berbasis Kriteria), dilakukan penyusunan kisi-kisi latihan pada Lembar Kerja Siswa dilngkapi dengan kunci jawaban dan pedoman penskoran. Selanjutnya, masuk pada media selection (pemilihan media). Bahan ajar yang dipilih dalam pengembangan program belajar ini adalah Lembar Kerja Siswa (LKS) dikarenakan sekolah SMA Panjura sudah terbiasa menggunakan LKS dalam pembelajarannya, akan tetapi LKS yang biasa digunakan belum menuntun pada pemahaman matematis siswa. Oleh karena itu, LKS yang 
disusun dilengkapi dengan Rencana Pelaksanaan Pembelajaran (RPP) yang mengarahkan siswa pada pemahaman matematis. Pada format selection (pemilihan format), dipilihlah Prinsip Progressive Differentiation dan Integrative Reconciliation yang digunakan dalam pembelajaran. Dari sini, disusunlah Initial Design (Rancangan Awal) yaitu Program Belajar siswa berupa Lembar Kerja Siswa (LKS) dilengkapi dengan Rencana Pelaksanaan Pembelajaran (RPP) menggunakan Prinsip Progressive Differentiation dan Integrative Reconciliation pada materi Pernyataan Majemuk dan Berkuantor.

\section{Develop}

Pada tahap Develop (Pengembangan), dilakukan Expert Appraisal (Penilaian Ahli) dan Developmental Testing (Uji Pengembangan). Expert Appraisal (Penilaian Ahli) oleh tiga dosen Pendidikan Matematika sebagai ahli pendidikan sekaligus ahli materi. Sedangkan
Developmental Testing (Uji Pengembangan) dilakukan kepada 25 siswa SMA Panjura Malang.

Rancangan perangkat pembelajaran yang telah divalidasi oleh tim ahli adalah Program belajar berupa Lembar Kerja Siswa (LKS) dilengkapi dengan Rencana Pelaksanaan Pembelajarannya (RPP) pada materi pernyataan majemuk dan berkuantor. Hasil validasi digunakan untuk menilai validitas perangkat sebelum pelaksanaan uji coba di lapangan, sedangkan hasil uji coba lapangan digunakan untuk menilai kepraktisan dan keefektifan perangkat pembelajaran. Hasil validasi dibuat keputusan, apakah perangkat masih perlu revisi sebelum uji coba atau telah siap diujicobakan di lapangan. Validator dalam penelitian ini terdiri dari tiga dosen pendidikan matematika.

Tabel di bawah ini merupakan hasil validasi Rencana Pelaksanaan Pembelajaran (RPP) dan hasil validasi Lembar Kerja Siswa (LKS).

Tabel 4. Data Penilaian Rencana Pelaksanaan Pembelajaran (RPP) oleh validator

\begin{tabular}{|c|c|c|c|c|c|c|c|}
\hline \multirow[b]{2}{*}{ No } & \multirow[b]{2}{*}{ Pernyataan } & \multicolumn{3}{|c|}{ Validator } & \multirow{2}{*}{$\sum^{3} x_{i}$} & \multirow{2}{*}{$\sum^{3} x_{j}$} & \multirow{2}{*}{$\underset{(\%)}{\mathbf{P}}$} \\
\hline & & $x_{1}$ & $x_{2}$ & $x_{3}$ & & & \\
\hline 1 & $\begin{array}{l}\text { Kegiatan pembelajaran pada RPP ini membuat siswa mampu } \\
\text { menentukan kriteria pembeda dimulai dari ide pokok "kalimat" } \\
\text { yaitu kalimat dibedakan menurut kriteria kejelasan nilai kebenaran } \\
\text { dan seterusnya }\end{array}$ & 3 & 4 & 3 & 10 & 12 & 83 \\
\hline 2 & $\begin{array}{l}\text { Kegiatan pembelajaran pada RPP ini membuat siswa mampu } \\
\text { menggolongkan sub bahasan berdasarkan kriteria pembeda } \\
\text { dimulai dari "pernyataan" dan "bukan pernyataan" dan seterusnya }\end{array}$ & 4 & 3 & 3 & 10 & 12 & 83 \\
\hline 3 & $\begin{array}{l}\text { Kegiatan pembelajaran pada RPP ini akan membuat siswa mampu } \\
\text { menyusun dan mengorganisir hierarki konsep logika }\end{array}$ & 4 & 3 & 2 & 9 & 12 & 75 \\
\hline 4 & $\begin{array}{l}\text { Kegiatan pembelajaran RPP ini akan membuat siswa mampu } \\
\text { menghubungkan konsep logika dengan konsep himpunan }\end{array}$ & 3 & 3 & 3 & 9 & 12 & 83 \\
\hline 5 & $\begin{array}{l}\text { Kegiatan pembelajaran pada RPP ini membuat siswa mampu } \\
\text { menemukan hubungan antar sub bahasan dalam konsep logika }\end{array}$ & 3 & 3 & 3 & 9 & 12 & 75 \\
\hline & Total & & & & 47 & 60 & 78 \\
\hline
\end{tabular}

Tabel 5. Data Penilaian Lembar Kerja Siswa (LKS)

\begin{tabular}{|c|c|c|c|c|c|c|c|}
\hline \multirow[b]{2}{*}{ No } & \multirow[b]{2}{*}{ Pernyataan } & \multicolumn{3}{|c|}{ Validator } & \multirow{2}{*}{$\sum_{i=1}^{3} x_{i}$} & \multirow{2}{*}{$\sum_{i=1}^{3} x_{f}$} & \multirow[b]{2}{*}{$\begin{array}{c}\mathrm{P} \\
(\%)\end{array}$} \\
\hline & & $x_{1}$ & $x_{2}$ & $x_{3}$ & & & \\
\hline 1 & $\begin{array}{l}\text { Sajian materi pada LKS ini membuat siswa mampu menentukan } \\
\text { kriteria pembeda dimulai dari ide pokok "kalimat" yaitu kalimat } \\
\text { dibedakan menurut kriteria kejelasan nilai kebenaran dan } \\
\text { seterusnya }\end{array}$ & 3 & 4 & 3 & 10 & 12 & 83 \\
\hline 2 & $\begin{array}{l}\text { Sajian materi pada LKS ini membuat siswa mampu } \\
\text { menggolongkan sub bahasan berdasarkan kriteria pembeda } \\
\text { dimulai dari "pernyataan" dan "bukan pernyataan" dan seterusnya }\end{array}$ & 3 & 3 & 4 & 10 & 12 & 83 \\
\hline 3 & $\begin{array}{l}\text { Sajian materi pada LKS ini akan membuat siswa mampu } \\
\text { menyusun dan mengorganisir hierarki konsep logika }\end{array}$ & 3 & 4 & 4 & 11 & 12 & 92 \\
\hline
\end{tabular}




\begin{tabular}{|c|c|c|c|c|c|c|c|}
\hline 4 & $\begin{array}{l}\text { Sajian materi pada LKS ini akan membuat siswa mampu } \\
\text { menghubungkan konsep logika dengan konsep himpunan }\end{array}$ & 4 & 3 & 2 & 9 & 12 & 75 \\
\hline 5 & $\begin{array}{l}\text { Sajian materi pada LKS ini membuat siswa mampu menemukan } \\
\text { hubungan antar sub bahasan dalam konsep logika }\end{array}$ & 4 & 3 & 3 & 10 & 12 & 83 \\
\hline & \begin{tabular}{|c|} 
Total \\
\end{tabular} & & & & 50 & 60 & 83 \\
\hline
\end{tabular}

Keterangan:

$x_{1} \quad$ : Validator 1

$x_{2} \quad$ : Validator 2

$x_{3} \quad$ : Validator 3

$\sum_{i=1}^{3} x_{i}:$ Jumlah skor penilaian

$\sum_{i=1}^{3} x_{j}$ : Jumlah skor penilaian maksimal

$\mathrm{P} \quad$ : Persentase penilaian

Berdasarkan tabel 4. tentang hasil validasi Rencana Pelaksanaan Pembelajaran (RPP) diperoleh persentase penilaian 78\%, maka sesuai dengan Jenjang Kualifikasi Penilaian dapat disimpulkan bahwa Rencana Pelaksanaan Pembelajaran (RPP) yang telah disusun adalah Valid sehingga tidak perlu direvisi. Sedangkan pada tabel 5. tentang hasil validasi Lembar Kerja Siswa (LKS) diperoleh persentase penilaian $83 \%$, maka sesuai dengan Jenjang Kualifikasi Penilaian dapat disimpulkan bahwa Lembar Kerja Siswa (LKS) adalah Sangat Valid sehingga tidak perlu direvisi.

Data praktikalitas LKS diperoleh dari lembar observasi keterlaksanaan LKS selama 8 kali pertemuan, angket kepraktisan LKS diberikan pada pertemuan keempat, dan hasil wawancara terhadap guru matematika yang mengajar di kelas tersebut. Hasil observasi keterlaksanaan menunjukkan bahwa LKS berbasis masalah praktis digunakan baik segi kemudahan penggunaan, isi, dan waktu. Hasil angket kepraktisan LKS dikategorikan praktis. Kepraktisan tersebut dapat dilihat dari keterbacaan, kemudahan, dan waktu yang efektif dan efisien dalam pemakaian LKS berbasis prinsip Progressive Differentiation dan Integrative Reconciliation. Petunjuk LKS mudah dipahami, LKS mudah digunakan, cara melengkapi bagian yang kosong pada LKS mudah dipahami, ukuran dan model huruf yang digunakan pada LKS mudah dipahami, dan kejelasan langkah-langkah yang diberikan pada LKS membuat siswa lebih mudah menemukan konsep materi Logika dikategorikan praktis. Pernyataan dan kalimat-kalimat pada LKS mudah dimengerti dan gambar yang disajikan pada LKS jelas yaitu $85 \%$ dikategorikan praktis. Waktu yang disediakan untuk menyelesaikan kegiatan pada LKS mencukupi dan sesuai dengan jam pelajaran yaitu $81,5 \%$ dikategorikan praktis. Berdasarkan uji kepraktisan yang dilakukan dapat disimpulkan bahwa LKS tergolong praktis.

Uji ahli Lembar Kerja Siswa (LKS) menunjukkan hasil valid dan telah diperbaiki menurut saran dan komentar ahli. Pada tahap ini diujicobakan pada 25 orang siswa. Uji coba LKS bertujuan untuk mengetahui tingkat pemahaman siswa terhadap sajian materi pada LKS. Pada tabel 6 . berikut adalah sajian data penilaian LKS.

Tabel 6. Penilaian Lembar Kerja Siswa (LKS) dan Pemahaman Siswa

\begin{tabular}{clccc}
\hline \multirow{2}{*}{ No } & \multirow{2}{*}{ Nama } & \multicolumn{3}{c}{ Nilai } \\
\cline { 3 - 5 } & & $\mathbf{A}$ & L1 & L2 \\
\hline 1 & ACH & 79 & 80 & 82 \\
\hline 2 & AKP & 81 & 81 & 78 \\
\hline 3 & ALP & 92 & 90 & 83 \\
\hline 4 & ASSA & 95 & 100 & 96 \\
\hline 5 & AYL & 77 & 76 & 83 \\
\hline 6 & BCK & 94 & 98 & 92 \\
\hline 7 & BFH & 86 & 89 & 87 \\
\hline 8 & BJOK & 78 & 68 & 74 \\
\hline 9 & DAM & 95 & 92 & 80 \\
\hline 10 & DPTG & 79 & 73 & 60 \\
\hline
\end{tabular}


JIPM (Jurnal Ilmiah Pendidikan Matematika), 7(2), Maret 2019- 81

Nathasa Pramudita Irianti, Elita Mega Selvia Wijaya

\begin{tabular}{clccc}
\hline 11 & EGC & 86 & 78 & 78 \\
\hline 12 & EJK & 81 & 80 & 78 \\
\hline 13 & FHKI & 94 & 83 & 85 \\
\hline 14 & KRA & 77 & 73 & 74 \\
\hline 15 & LAD & 78 & 78 & 80 \\
\hline 16 & LIA & 81 & 80 & 92 \\
\hline 17 & MUA & 92 & 91 & 88 \\
\hline 18 & MKI & 95 & 87 & 80 \\
\hline 19 & NJK & 92 & 86 & 83 \\
\hline 20 & NKO & 77 & 82 & 80 \\
\hline 21 & PGIA & 94 & 74 & 73 \\
\hline 22 & PJIA & 86 & 80 & 82 \\
\hline 23 & SIA & 78 & 70 & 78 \\
\hline 24 & YGH & 86 & 83 & 80 \\
\hline 25 & ZIA & 79 & 80 & 78 \\
\hline JUMLAH & 2.132 & 2.052 & 2.024 \\
\hline RATA-RATA & 85,28 & 82,08 & 80,96 \\
\hline \multicolumn{5}{c}{}
\end{tabular}

Keterangan:

$\begin{array}{ll}\text { A } & \text { : Aktivitas Siswa } \\ \text { L1 } & \text { : Bermain dengan Logika I } \\ \text { L2 } & \text { : Bermain dengan Logika II }\end{array}$

Pada aspek aktivitas siswa, uji coba mendapatkan rata-rata nilai 85,28 . Berdasarkan skala penilaian tingkat pemahaman siswa, diperoleh kesimpulan bahwa uji coba terhadap siswa termasuk dalam kategori sangat baik dalam mencapai indikator aspek aktivitas pada Lembar Kerja Siswa. Pada latihan bermain dengan Logika I, siswa mendapatkan rata-rata nilai 82,08 . Berdasarkan skala penilian tingkat pemahaman siswa, diperoleh kesimpulan bahwa uji coba terhadap siswa termasuk dalam kategori sangat baik. Pada latihan bermain dengan Logika II, uji coba terhadap siswa mendapatkan rata-rata nilai 80,96 . Berdasarkan skala penilian tingkat pemahaman siswa, diperoleh kesimpulan bahwa uji coba terhadap siswa juga termasuk dalam kategori sangat baik. Dengan demikian, program belajar siswa berupa LKS dilengkapi dengan rencana pelaksanaan pembelajarannya dapat dikatakan praktis dan efektif untuk digunakan.

\section{Hasil Akhir Pengembangan}

Rancangan program belajar berupa Rencana Pelaksanaan Pembelajaran (RPP) dan Lembar Kerja Siswa (LKS) telah melewati tahap uji ahli dan memperoleh hasil yang valid. Perangkat pembelajaran tersebut kemudian diperbaiki berdasarkan saran dan komentar para ahli. Pada tahap selanjutnya, Lembar Kerja Siswa (LKS) diujicobakan pada 25 siswa. Pada LKS terdapat aspek aktivitas siswa, latihan
Bermain dengan Logika I, dan latihan Bermain dengan Logika II. Analisis data uji coba menunjukkan bahwa uji coba terhadap siswa telah mencapai indikator baik sekali di aspek aktivitas siswa. Sedangkan pada latihan Bermain dengan Logika I dan II telah mencapai indikator baik. Dengan demikian dapat disimpulkan bahwa program belajar berbasis prinsip Progressive Differentiation dan Integrative Reconciliation praktis dan efektif untuk diterapkan. Hal ini sesuai dengan hasil penelitian Harefa(Otoni, 2013) dan Darmansyah(Darmansyah, 2017) bahwa prinsip Progressive Differentiation dan Integrative Reconciliation dapat meningkatkan pemahaman matematis siswa.

Setelah melalui proses penilaian tersebut diperoleh hasil akhir pengembangan program belajar berupa Rencana Pelaksanaan Pembelajaran (RPP) dan Lembar Kerja Siswa ( LKS) Materi Pernyataan Majemuk dan Berkuantor sebagai berikut.

\section{a. Rencana Pelaksanaan Pembelajaran (RPP)}

Kegiatan pembelajaran pada Rencana Pelaksanaan Pembelajaran (RPP) berbasis prinsip Progressive Differentiation dan Integrative Reconciliation terdiri dari 8 pertemuan, masing-masing pertemuan dialokasikan sebanyak 2 X 40 menit. Pada lampiran RPP terdapat Kunci Lembar Kerja Siswa (LKS), Kunci Bermain dengan Logika I dan II, serta Rubrik Penilaian Aktivitas Siswa, 
Rubrik Penilaian Latihan Bermain dengan Logika dan Rubrik Pengamatan Sikap.

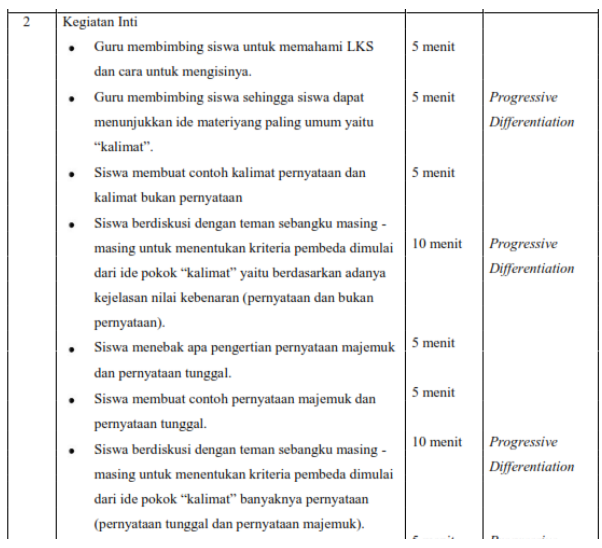

Gambar 2. Bagian dari Rencana Pelaksanaan Pembelajaran (RPP) berbasis Prinsip Progressive Differentiation dan Integrative Reconciliation

\section{b. Lembar Kerja Siswa (LKS)}

Sajian materi pada LKS telah mencakup kriteria prinsip Progressive Differentiation dan Integrative Reconciliation. LKS terdiri atas Bagian 1, Bagian 2, dan Latihan. Bagian 1 dan 2 memuat sajian materi dan aktivitas siswa. Rincian Lembar Kerja Siswa yang menggunakan prinsip Progressive Differentiation dan Integrative Reconciliation ini adalah sebagai berikut:

1. Judul LKS

2. Nama Mata Pelajaran, Pokok Bahasan

3. Petunjuk Penggunaan

4. Kompetensi Dasar yang akan Dicapai

5. Indikator

6. Informasi sebagai pendukung siswa dalam melakukan aktivitasnya menggunakan LKS

7. Tugas, pertanyaan, dan langkah kerja terstruktur

8. Soal evaluasi dan kunci jawaban
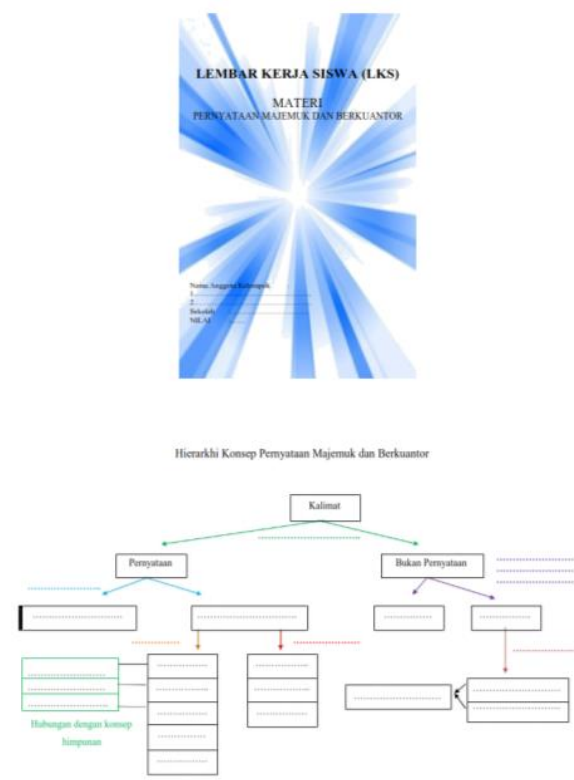

Gambar 3. Bagian dari Lembar Kerja Siswa (LKS) berbasis Prinsip Progressive Differentiation dan Integrative Reconciliation

\section{SIMPULAN}

Berdasarkan hasil analisis data, program belajar matematika berupa Lembar Kerja Siswa (LKS) beserta Rencana Pelaksanaan Pembelajarannya (RPP) berdasarkan Prinsip Progressive Differentiation dan Integrative Reconciliation yang dikembangkan valid, praktis, dan efektif untuk diterapkan dalam pembelajaran.

Hal ini ditunjukkan dari hasil uji ahli kepada tiga dosen Pendidikan Matematika sebagai ahli pendidikan dan juga ahli materi yang memberikan hasil valid. Uji kepraktisan yang dilakukan mendapatkan hasil 85\% dan 81,5\% masuk dalam kategori praktis untuk diterapkan. Data keefektifan LKS diperoleh dari hasil belajar siswa. Hasil tes belajar siswa uji coba latihan I dan II yang masing-masing mendapatkan skor rata-rata 82,08 dan 80,96 yang juga masuk dalam kategori sangat baik sehingga efektif untuk diterapkan dalam pembelajaran. 


\section{DAFTAR PUSTAKA}

Afrilianto, M. (2012). Peningkatan pemahaman konsep dan kompetensi strategis matematis siswa smp dengan pendekatan metaphorical thinking. Infinity Jurnal Ilmiah Program Studi Matematika STKIP Siliwangi Bandung, 1(2), 192-202. https://doi.org/10.22460/infinity.v1i2.19

Alawiah, L. T., Rahmatina, D., \& Febrian. (2018). Meningkatkan Kemampuan Berpikir Kritis melalui Alat Peraga Pilogma pada Materi Logika Matematika. Jurnal Gantang, III(1), 55-62.

Anderson, L. W., Krathwohl, D. R., Airasian, P. W., Cruikshank, K. A., Mayer, R. E., \& Pintrich, P. R. (2001). A taxonomy for learning. Teaching, and.

Arikunto. (2010). Prosedur Penelitian Suatu Pendekatan Praktik. Rineka Cipta. Jakarta. https://doi.org/10.1016/j.minpro.2005.02.0 05

Ausubel, D. P. (1963). The psychology of meaningful verbal learning. Grune and Stratton, 58. https://doi.org/10.1097/00000441196402000-00048

Bani, A. (2011). Meningkatkan Kemampuan Pemahaman dan Penalaran Matematik Siswa Sekolah Menengah Pertama Melalui Pembelajaran Penemuan Terbimbing, SPS UPI, Bandung. Edisi Khusus, (1), 12-20.

Crawford, M. L. (2001). Teaching Contextually: Research, Rationale, and Techniques for Improving Student Motivation and Achievement in Mathematics and Science. Teaching Contextually (2001st ed.). Texas: CCI Publishing, Inc.

Darmansyah. (2017). Efektivitas Penerapan Model Pembelajaran Advance Organizer Berbantuan Kartun Humor Terhadap Hasil Belajar. Prosiding Seminar Nasional Pascasarjana (SNP) Unsyiah 2017, 19-24.

Febriyanto, B., Haryanti, Y. D., \& Komalasari, O. (2018). Peningkatan Pemahaman Konsep Matematis melalui Penggunaan Media Kantong Bergambar pada Materi Perkalian Bilangan di Kelas II Sekolah Dasar, 4(2).

Gazali, R. Y. (2016). Pengembangan Bahan Ajar Matematika untuk Siswa SMP Berdasarkan Teori Belajar Ausubel Development of Mathematics Teaching Material for Junior High School Students
Based on Ausubel Learning Theory. Jurnal Pendidikan Matematika, 11(2), 182-192.

Harini, L. P. I., \& Oka, T. B. (2016). Penggunaan Mind Map dalam Pembuktian Matematika. Jurnal Matematika, 6(1), 5667.

Huda, N., \& Kencana, A. G. (2013). Analisis Kesulitan Siswa Berdasarkan Kemampuan Pemahaman dalam Menyelesaikan Soal Cerita pada Materi Kubus dan Balok Di Kelas VIII SMP Negeri 30 Muaro Jambi. Prosiding Semirata FMIPA Lampung, 1, 595-606.

Irianti, N., Subanji, \& Chandra, T. (2016). Proses Berpikir Siswa Quitter dalam Menyelesaikan Masalah SPLDV berdasarkan Langkah-langkah Polya. Jurnal Matematika Dan Pendidikan Matematika, I(2), 133-142.

Johnson, E. B. (2002). Contextual Teaching and Learning: What It is and Why It's Here to Stay. California: Corwin Press.

Kilpatrick, E., National, D. C., \& Press, A. (2002). Zdm026RI (Vol. 34).

Maisari Dwi, Suyadi Gimin, A. R. (2013). Pengaruh Model Pembelajaran Kooperatif Tipe Make a Match Terhadap Pemahaman Konsep Matematis (Studi pada Siswa Kelas VIII Semester Ganjil SMPN 5 Bandar Lampung tahun pelajaran 2012/2013), 2(1), 1-6.

Mathematics, N. C. O. T. O. (2000). Principles and Standards for School Mathematics. School Science and Mathematics, 47(8), 279-868. https://doi.org/10.1111/j.19498594.2001.tb17957.x

Murizal, A., Yarman, yarman, \& Yerizon, Y. (2012). Pemahaman Konsep Matematis dan Model Pembelajaran Quantum Teaching. Jurnal Pendidikan Matematika, 1(1), 19-23.

Musrikah, M. (2016). Model Pembelajaran Matematika Realistik sebagai Optimalisasi Kecerdasan Logika Matematika pada Siswa SD/MI. Ta'allum: Jurnal Pendidikan Islam, 4(1), 1-18. https://doi.org/10.21274/taalum.2016.4.01. 1-18

Ningsih, P. R. (2013). Penerapan Metode Realistic Mathematics Education (RME) Pada Pokok Bahasan Perbandingan Senilai dan Berbalik Nilai Di Kelas VII E SMP IPIEMS Surabaya. Gamatika, III(2), 177184. 
Otoni, H. A. (2013, April). Penerapan Teori Pembelajaran Ausebel dalam Pembelajaran. Universitas Dharmawangsa, 43-55.

Pendidikan, N. D. (2007). Materi Sosialisasi dan Pelatihan Kurikulum Tingkat Satuan Pendidikan (KTSP). Jakarta: Departemen Pendidikan Nasional. https://doi.org/10.1248/cpb.37.3229

Pramuditya, S. A., Noto, M. S., \& Purwono, dan H. (2018). Desain Game Edukasi Berbasis Android pada Materi Logika Matematika. Jurnal Nasional Pendidikan Matematika, 2(2), 165-179.

Prastowo, A. (2015). Panduan Kreatif Membuat Bahan Ajar Inovatif. Yogyakarta: Diva Press.

Riduwan. (2006). Belajar Mudah Penelitian untuk Guru, Karyawan, Peneliti Pemula. Bandung: Alfabeta.

Slavin, R. E. (1997). Educational psychology: Theory and practice (5th ed.). Educational Psychology: Theory and Practice (5th Ed.).

Sukmara, C. (2011). Pembelajaran Kooperatif
NHT (Numbered Heads Together) dalam Upaya Meningkatkan Prestasi Belajar Matematika Siswa di SMP Negeri 1 Sukarame Kabupaten Tasikmalaya Jawa Barat. Jurnal Saung Guru, II(2), 15-23.

Thiagarajan, \& Sivasailam. (1920). Instructional Development for Training Teachers of Exceptional, (Mc).

Travers, J. F., Elliott, S. N., \& Kratochwill, T. R. (1993). Educational psychology: Effective teaching, effective learning. Educational psychology: Effective teaching, effective learning.

Wijaya, E., \& Irianti, N. (2017). Whole Brain Teaching sebagai Desain Pembelajaran Matematika yang Kreatif. Must: Journal of Mathematics Education, Science, and Technoloogy, 2(2), 196-207.

Yulianti, E., Zulkardi, Z., \& Siroj, R. A. (2010). Pengembangan Alat Peraga Menggunakan Rangkaian Listrik Seri-Paralel Untuk Mengajarkan Logika Matematika Di Smk Negeri 2 Palembang. Jurnal Pendidikan Matematika, 4(1). https://doi.org/10.22342/jpm.4.1.308. 